\title{
JEDNOSTKI WOJSK RAKIETOWYCH I ARTYLERII W GARNIZONIE ORZYSZ PO 1945 ROKU - WPŁYW NA ROZWÓJ I FUNKCJONOWANIE MIASTA
}

\begin{abstract}
Streszczenie. Artykuł przedstawia rozwój i funkcjonowanie miejscowości Orzysz, jako miasta od połowy XVIII w. nierozerwalnie związanego z wojskiem. Na rozwój gospodarczy miasta korzystnie wpłynęła decyzja o umiejscowieniu w 1890 r. pod miastem poligonu. Druga wojna światowa, a szczególnie ustalenia aliantów w Teheranie i Jałcie zmieniły oblicze miasta. Orzysz znalazł się w granicach Polski, w znacznym stopniu wyludniony i zniszczony. Pozostała jednak nienaruszona poniemiecką infrastruktura wojskową, która stała się miejscem dyslokacji od 1948 r. jednostek artylerii, a w latach sześćdziesiątych rakietowych Wojska Polskiego. Wojsko, pomagając miejscowej ludności, stało się szczególnie po wojnie gwarantem bezpieczeństwa dla ludności napływającej z centralnej Polski i utraconych ziem na wschodzie. Istotny wpływ na rozwój miasta mieli służący żołnierze i kadra zawodowa. Także rodziny kadry uczestniczyły w życiu cywilnym Orzysza. Jednak przesadzona ochrona kontrwywiadowcza zahamowała rozwój niektórych gałęzi gospodarki, a zwłaszcza turystyki, spychając miasto do roli usługodawczej wobec wojska.
\end{abstract}

Słowa kluczowe: Wojsko Polskie, Orzysz, garnizon, mieszkańcy, wojska rakietowe i artylerii

\section{Wprowadzenie}

Organizacja i funkcjonowanie Wojska Polskiego po drugiej wojnie światowej kształtowały się w ścisłym powiązaniu z sytuacją międzynarodową i z nową rzeczywistością polityczną, w jakiej znalazło się państwo polskie. Pokojowa organizacja wiązała się z nowym kształtem terytorium państwa, w tym ustaleniem dyslokacji uwzględniającej Ziemie Zachodnie i Północne wraz z Warmią i Mazurami. 
Wojsko na obszarze Polski północnej (przez który rozumiemy obecny teren województwa warmińsko-mazurskiego) odgrywało zawsze specyficzną rolę. Do 1945 roku obszar ten w ramach niemieckiej prowincji Prusy Wschodnie był w okresie III Rzeszy jednym wielkim garnizonem, stając się jednocześnie świadkiem jednych z najkrwawszych walk w czasie II wojny światowej.

Los ziem leżących w granicach Prus Wschodnich został przesądzony na konferencji „Wielkiej Trójki” w Teheranie, a potwierdzony w Jałcie. Prowincja miała przestać istnieć, a jej obszar miał się znaleźć w granicach Polski i Związku Radzieckiego. W momencie przejęcia południowej części Prus Wschodnich (Warmia, Mazury i Powiśle) przez administrację polską w 1945 r., jedynie Wojsko Polskie dawało gwarancję trwałej obecności na tych ziemiach. Jak wiadomo, nie tylko zajmowało się szkoleniem i przygotowaniem do konfrontacji z Zachodem, ale również pełniło funkcje administracyjne, gospodarcze czy społeczne, dając poczucie stabilizacji ludności napływającej z centralnej Polski i utraconych ziem na wschodzie. Niestety, odgrywało też rolę instrumentu w rękach nowej władzy, wspierając partyjną administrację i siły bezpieczeństwa.

Celem artykułu jest przedstawienie rozwoju i funkcjonowania miejscowości Orzysz, jako miasta od połowy XVIII w. nierozerwalnie związanego z wojskiem. Na rozwój gospodarczy miasta korzystnie wpłynęła decyzja o umiejscowieniu w 1890 r. pod miastem poligonu. Druga wojna zmieniła oblicze miasta. Orzysz znalazł się w granicach Polski, w znacznym stopniu wyludniony i zniszczony. Pozostała jednak nienaruszona poniemiecką infrastruktura wojskową, która stała się miejscem dyslokacji od 1948 r. jednostek artylerii, a w latach sześćdziesiątych rakietowych Wojska Polskiego. Wojsko, pomagając miejscowej ludności, stało się szczególnie po wojnie gwarantem bezpieczeństwa dla ludności napływającej z centralnej Polski i utraconych ziem na wschodzie. Istotny wpływ na rozwój miasta mieli służący żołnierze i kadra zawodowa. Także rodziny kadry uczestniczyły w życiu cywilnym Orzysza. Jednak przesadzona ochrona kontrwywiadowcza zahamowała rozwój niektórych gałęzi gospodarki, a zwłaszcza turystyki, spychając miasto do roli usługodawczej wobec wojska.

Niestety, literatura dotycząca wpływu Wojska Polskiego na rozwój i funkcjonowanie miast Warmii i Mazur jest dość uboga. Ukazało się jedynie kilka 
publikacji, w których obecna jest ta tematyka. Można do nich zaliczyć opracowania dotyczące takich garnizonów jak Bartoszyce ${ }^{1}$, Węgorzewo ${ }^{2}$ czy Ostróda ${ }^{3}$.

Materiały źródłowe związane z tym tematem znajdują się w Centralnym Archiwum Wojkkowym oraz wojskowych archiwach w Oleśnicy i Toruniu. Problematykę funkcjonowania wojsk rakietowych i ich wpływ na funkcjonowanie Orzysza przedstawił Michał Trubas w artykule pt. Kolebka polskich wojsk rakietowych ${ }^{4}$. Autorem, który opublikował najwięcej na temat wojskowej historii Orzysza jest Waldemar Brenda, który ujął historię garnizonu w artykule pt. Militarne dzieje Ziemi Piskiej wXX w. , a w miesięczniku „Debata” zamieścił liczne artykuły poświęcone dziejom wojskowym Ziemi Piskiej. Ciekawym źródłem na temat służby wojskowej w Orzyszu jest również pamiętnik Mariana Laszczyka ${ }^{6}$.

\section{Dzieje wojskowe Orzysza do 1945 r.}

Miasto i gmina Orzysz są położone w południowo-wschodniej części Krainy Wielkich Jezior Mazurskich. Administracyjnie wchodzą w skład powiatu piskiego, który znajduje się w granicach województwa warmińsko-mazurskiego. Znane głównie jako garnizon wojskowy, do końca drugiej wojny światowej nosiło nazwę Arys.

Początek miasta, zwanego niegdyś przed nadaniem praw miejskich Orzeszem, Rozyszem czy też Arysem, sięga XV wieku. Miejscowa i okoliczna ludność polska miała nazywać osadę Orzyszczem, od obfitości leszczyn w jej pobliżu.

${ }^{1}$ Garnizony artyleryjskie na Warmii i Mazurach, cz. 1: Artyleryjskie rzemiosto. Wspomnienia żotnierzy 1 Berlińskiego Putku Artylerii w Bartoszycach, red. E. PAWLICA, Węgorzewo 2014.

${ }^{2}$ Garnizony artyleryjskie na Warmii i Mazurach, cz. 2: Artyleria Polska w XX wieku. W 70 rocznice powstania 1 Warszawskiej Brygady Artylerii Armat im. gen. J. Bema w Wegorzewie, red. W.B. ŁACH, Węgorzewo 2014.

3 W. KoŁodZIEJ, Ostróda miasto garnizonowe, Ostróda 2011.

${ }^{4}$ M. TRuBas, Kolebka polskich wojsk rakietowych, [w:] $Z$ dziejów Wojska Polskiego na Warmii i Mazurach po drugiej wojnie światowej, red. W.B. ŁACH, Węgorzewo 2004.

5 W. Brenda, Militarne dzieje Ziemi Piskiej wXX w., [w:] Dzieje Militarne Krainy Wielkich Jezior Mazurskich, red. W.B. ŁaCH, D. RADZIWIŁŁOWICZ, S. JANOWICZ, Wilkasy 2013.

${ }^{6}$ M. LASZCZYK, Zapisane w pamięci, Warszawa 2004. 
Po wojnie nawiązano do tej historycznej nazwy i w listopadzie 1946 r. zmieniono niemiecko brzmiącą nazwę miasta na Orzysz?.

Król Prus Fryderyk Wilhelm I 1 marca 1725 r. nadał Orzyszowi prawa miejskie; miasto otrzymało również aktualny do dnia dzisiejszego herb przedstawiający orła trzymającego w szponach róg obfitości, w którym skrzyżowane są berło i szpada. Obszar Orzysza nigdy nie był gęsto zaludniony. Słabe gleby, duże obszary wód i lasów nie zachęcały do osadnictwa. Wojny i choroby pustoszyły kraj. W roku 1740 Orzysz liczył 640 mieszkańców, a ludność miasta trudniła się rzemiosłem, handlem, rolnictwem i rybołówstwem ${ }^{8}$.

Przełomowym wydarzeniem dla przyszłego kierunku rozwoju miasta było założenie w 1753 r. garnizonu wojskowego. Wspomniany fakt przyczynił się do rozwoju handlu i usług. W okresie brandenbursko-pruskim stacjonowały tu m.in. pododdziały 11. pułku garnizonowego, 14. i 16. pułku piechoty, 5. i 8. pułku huzarów oraz 9. pułku „Bośniaków”.

Na rozwój miasta korzystnie wpłynęła decyzja o umiejscowieniu w $1890 \mathrm{r}$. pod miastem poligonu. Na jego lokalizację z pewnością miało wpływ kilka czynników. Zaliczyć do nich należy niewielką gęstość zaludnienia i położenie poligonu wśród lasów i jezior. Dużym plusem była również dobra infrastruktura drogowa i kolejowa, która stwarzała możliwość przerzutu wojska i sprzętu z centralnych regionów Niemiec ${ }^{10}$.

Jedną z konsekwencji powstania poligonu była budowa i uruchomienie w 1905 r. linii kolejowej z Pisza. Rok później ukończono budowę kolei do Giżycka, a już w czasie wojny światowej, czyli w 1915 r., utworzono połączenie na trasie Mrągowo-Orzysz-Ełk. Te zmiany znalazły odzwierciedlenie w rozwoju gospodarczym i turystycznym, przekładając się na wzrost liczby mieszkańców, których w 1910 r. było $2201^{11}$. Budowa od 1895 r. trwałych obiektów dla wojska sprawiła, że Orzysz otrzymał status miasta garnizonowego. W pierwszym dziesięcioleciu XX w. baraki zostały zastąpione 80 budynkami koszarowymi

\footnotetext{
7 Piszz dziejów miasta i powiatu, red. W. KorYCKa, Olsztyn 1970, s. 191; Orzysz-historia, www. orzysz.pl (dostęp: 2 I 2020).

8 Pisz z dziejów..., s. 191-192.

915 Gizycka Brygada Zmechanizowana im. Zawiszy Czarnego 1994-2016, red. R. KEMPA, A. Prokopczuk, Giżycko 2016, s. 78; Orzysz - historia...

10 W. BRENDA, op. cit., s. 133; 15 Giżycka Brygada..., s. 78-79; Orzysz - historia...

11 W. BRENDA, op. cit., s. 134; 15 Giżycka Brygada..., s. 79.
} 
dla żołnierzy i oficerów. Powstało w ten sposób prawdziwe wojskowe miasto, obszarowo i pod względem liczby mieszkańców większe od Orzysza ${ }^{12}$.

Niemieckie przygotowania do pierwszej wojny światowej w okolicach Orzysza nie ograniczały się do rozbudowy infrastruktury poligonowej i komunikacyjnej. Pod koniec XIX w. rozpoczęto budowę umocnień polowych i stałych w południowej części Wielkich Jezior Mazurskich, mających ochraniać pogranicze Prus Wschodnich ${ }^{13}$. Wojna nie oszczędziła Orzysza, ciężkie walki jesienią 1914 r. spowodowały, że miasto uległo zniszczeniu, a ludność w większości opuściła miasto. Po wojnie przegrane Niemcy dotknął szereg politycznych i militarnych ograniczeń, które skutkowały zmniejszeniem liczby jednostek. W związku z tymi zmianami w 1918 r. na pewien czas nawet zamknięto poligon. Miasteczko, niegdyś dynamicznie się rozwijające, musiało sobie radzić z licznymi problemami ekonomicznymi ${ }^{14}$.

Okres prosperity wrócił do Orzysza wraz z przejęciem władzy przez Adolfa Hitlera. W 1935 r. w Niemczech przywrócono powszechny obowiązek służby wojskowej. Infrastruktura koszarowa i tutejszy poligon nie tylko stały się znów potrzebne, ale wręcz wymagały nowych inwestycji. Nie ograniczono się do samego tylko powiększenia terenu przeznaczonego do wojskowych ćwiczeń. W samym Orzyszu zmodernizowano stare koszary, nadając im nazwę Arys Nord ${ }^{15}$.

W 1939 r. poligon przemianowano na Obóz Ćwiczebny Orzysz i zgrupowano na nim oddziały Wehrmachtu, m.in. kawalerii pancernej, które we wrześniu tegoż roku brały udział w ataku na Polskę. W chwili rozpoczęcia ofensywy styczniowej w 1945 r. Orzysz znalazł się w pasie natarcia 2. Frontu Białoruskiego. W ostatniej chwili przed nadejściem Armii Czerwonej władze niemieckie podjęły decyzję o ewakuacji mieszkańców miasta.

Armia Czerwona 23 stycznia 1945 r. zajęła Orzysz bez walki. Mimo to część miasta uległa zniszczeniu. Sowieci spalili czterdzieści budynków mieszkalnych, a także ratusz, plebanię, sąd rejonowy, budynek administracyjny komendantury i dwa budynki koszarowe ${ }^{16}$. Zmieniło się oblicze ludnościowe i administracyjne

12 W. BRENDA, op. cit., s. 135-136.

13 W. RuŻEwICZ, Fortyfikacje nowożytne Prus Wschodnich. Przewodnik, Łódź 2006, s. 41-44; P. BUJAS, Blokhauzy wieżowe węzta oporu Ruciane - Guzianka, „Forteca” 1997, nr 1, s. 24-30.

14 W. BRENDA, op. cit., s. 145-147.

1515 Gizycka Brygada..., s. 80.

${ }^{16}$ Ziemia Orzyska. Arys... Pamiętam takie miasto. I remember such city, Orzysz 2019, s. 40. 
Orzysza. Miasto znalazło się pod władzą sowieckiej komendantury wojennej. Rozpoczął się demontaż poniemieckich zakładów pracy i mienia ruchomego, m.in. rozebrano tory kolejowe na trasie Orzysz-Pisz ${ }^{17}$. Dopiero w sierpniu sowiecka komendantura wojenna dopuściła do miasta polskich przedstawicieli. W samym mieście pod koniec 1945 r. było około 300 mieszkańców, w większości Mazurów ${ }^{18}$.

Znacznie lepiej na tle rozszabrowanej infrastruktury cywilnej przedstawiał się stan znajdujących się w Orzyszu obiektów wojskowych, które były zajęte przez Armię Czerwoną do 1946 r. Wszystkie obiekty koszarowe znajdowały się w dobrym stanie, oprócz dwóch spalonych. Przy zniszczeniach i stanie obiektów wojskowych znajdujących się w centrum kraju stanowiły one doskonałą bazę szkoleniową w większości wykorzystywaną do dnia dzisiejszego.

\section{Orzysz w okresie stacjonowania jednostek artylerii Wojska Polskiego}

Naczelne Dowództwo Wojska Polskiego 1 lutego 1945 roku wydało rozkaz $\mathrm{Nr}$ 23/Org., nakazujący powołanie Warszawskiego Okręgu Wojskowego (dalej: OW I) z siedzibą w Warszawie, jednak wytyczony w rozkazie zasięg terytorialny nie obejmował przyznanego Polsce obszaru byłych Prus Wschodnich. Dopiero dwa miesiące później rozkazem Nr 0092/Org. włączono ten teren w obręb okręgu ${ }^{19}$.

W tym momencie infrastruktura okręgu została znacząco wzmocniona. $\mathrm{Na}$ terenie Orzysza znajdowało się pięć kompleksów wojskowych, z czego tylko w jednym pozostały budynki starsze z czasów sprzed I wojny światowej.

${ }^{17}$ L. Kowalski, Proces przejmowania bytych ziem Prus Wschodnich w granice państwa polskiego. Aspekty polityczno-gospodarczo-militarne, [w:] Dziatania militarne w Prusach Wschodnich, red. W. WRÓBLEWSKI, Warszawa 1998, s. 348-349.

18 Orzysz - historia...

19 W.B. ŁACH, Warmia i Mazury w systemie obronnym Polski po II wojnie światowej-jednostki liniowe Wojska Polskiego w wybranych garnizonach, [w:] Wojsko Polskie w nowej rzeczywistości spoteczno-politycznej po II wojnie światowej, t. 2, red. H. ŁACH, Olsztyn 2016, s. 172; Warszawski Okreg Wojskowy. Historia i wspótczesność, red. W. RozBICKI, Warszawa 1997, s. 31-32. 
W dobrym stanie były drogi i mimo demontażu cześć linii kolejowych można było odtworzyć połączenie kolejowe do Ełku i Olsztyna ${ }^{20}$.

Orzysz był bardzo ważnym garnizonem ze względu na znajdujący się tam poniemiecki poligon, który należało uruchomić w związku z potrzebą szkolenia wojska przechodzącego na etat w czasach pokoju. W rozkazie organizacyjnym nr 0236/Org. z 8 września 1945 r. naczelny dowódca Wojska Polskiego rozkazał utworzyć przy nowo powstałym Warszawskim Okręgu Wojskowym Okręgowy Poligon Artyleryjski. Uruchomienie poligonu spowodowało, że pod koniec lat czterdziestych w Orzyszu rozpoczęto organizować jednostki artyleryjskie. W czerwcu 1948 r. jako pierwszy został sformowany pułk artyleryjskiego rozpoznania pomiarowego w Orzyszu ${ }^{21}$.

Wiosną 1951 r. niepewna sytuacja międzynarodowa wymusiła wprowadzenie planu przyśpieszonego rozwoju wojska, czego efektem była sformowana 8. Dywizja Artylerii Przełamania z dowództwem w Orzyszu. Zasadniczy dokument powołujący do życia 8. Dywizję Artylerii Przełamania stanowił rozkaz Ministra Obrony Narodowej Nr 0043/Org. z 17 maja 1951 r. Rodowód 8. Dywizji Artylerii Przełamania związany jest z 2. Łużycką Dywizją Artylerii, która w okresie wojny wspierała jednostki bojowe Wojska Polskiego. W oparciu o rozwiązaną 12. Łużycką Brygadę Artylerii Ciężkiej, na bazie dowództwa brygady, sztabu, baterii dowodzenia, 68. i 70. pułku artylerii haubic przystąpiono do organizowania dywizji. Stan osobowy 8. Dywizji Artylerii Przełamania, łącznie z pracownikami kontraktowymi, liczył 6177 osób, w tym: 846 oficerów, 1504 podoficerów, 3855 szeregowych i 168 pracowników kontraktowych. Dowódcą dywizji został płk Piotr Posławski ${ }^{22}$.

${ }^{20}$ M. ZINIEWICZ, Wojskowa infrastruktura techniczna z czasów I wojny światowej obecnie wykorzystywana przez resort obrony narodowej, [w:] Wielka wojna na Mazurach 1914-1915. Studia z dziejów frontu wschodniego I wojny światowej, red. R. KEMPA, Węgorzewo 2014, s. 429-431; W. BRENDA, op. cit., s. 149-150.

${ }^{21}$ Centralne Archiwum Wojskowe Wojskowego Biura Historycznego (dalej: CAW WBH), Sztab Generalny Wojska Polskiego (dalej: SG WP), sygn. IV.501.1/A.164, Rozkaz organizacyjny ministra Obrony Narodowej nr 0120/Org. z 10 VI 1948 r., karty bez paginacji; W.B. ŁACH, op. cit., s. 184; http://ospwlorzysz.wp.mil.pl/ (dostęp: 8 I 2021); W. BRENDA, op. cit., s. 163.

22 Archiwum Wojskowe w Oleśnicy (dalej: AWO), 8 Dywizja Przełamania, sygn. 4004/10/8, Rozkazy i zarządzenia organizacyjne oraz wykazy zmian w etatach, karty bez paginy; W.B. ŁACH, op.cit., s. 186. 
Od tego momentu Orzysz zaczął ponownie nabierać charakterku operacyjnego, gdyż tworzona dywizja miała działać na rzecz 8. Korpusu Piechoty (w późniejszym okresie Korpus Armijny) z dowództwem w Olsztynie. W skład 8. dywizji wchodziły: dowództwo dywizji, bateria dowodzenia, 26. Brygada Artylerii Haubic w Orzyszu, 29. Brygada Artylerii Haubic w Bemowie Piskim, 15. Brygada Artylerii Ciężkiej i dywizjon artyleryjskiego rozpoznania pomiarowego w Węgorzewie ${ }^{23}$.

W dywizji, a w tym również i brygadach, zachodziły częste zmiany organizacyjne, które negatywnie wpływały na szkolenie i nastroje kadry. Dodatkowo zachodziły również zmiany w podporządkowaniu dywizji. W czerwcu 1953 r. utworzono dodatkowo 24. Brygadę Moździerzy Ciężkich w Orzyszu. Równocześnie rozpoczęto rozbudowę 8. Dywizji Artylerii Przełamania, zwiększając liczbę brygad artylerii haubic z dwóch do czterech (sformowano nową 32. Brygadę Artylerii Haubic i 34. Brygadę Artylerii Haubic Ciężkich). Ostatnie zmiany organizacyjne miały miejsce w październiku 1958 r., kiedy 8. Dywizję Artylerii Przełamania przemianowano na dywizję artylerii, a 32. Brygadę Artylerii Haubic i 24. Brygadę Moździerzy Ciężkich w znacznym stopniu skadrowano. W 1960 r. sztab dywizji przeniesiono do Giżycka, a rok później, 30 października, dywizję rozwiązano ${ }^{24}$.

W tym okresie sytuacja w mieście zaczęła się w miarę stabilizować. Powoli tworzono infrastrukturę miejską. I tak jeszcze w 1945 r. otwarto Szkołę Podstawową nr 1, w 1947 r. powstała Gminna Spółdzielnia „Samopomoc Chłopska” oraz Spółdzielnia Pracy Metalowców. W tym samym roku stworzono również Ochotniczą Straż Pożarną, w 1948 r. bibliotekę miejską, a rok później pralnię świadczącą usługi na potrzeby wojska. Odbudowana została infrastruktura kolejowa zapewniająca komunikację z Białymstokiem i Olsztynem. W 1947 r. miasto liczyło 1431, a w 1950 r. 2031 mieszkańców. Jak widać, przyrost demograficzny z owego czasu był skutkiem przemieszczeń ludności z różnych regionów Polski, przeważnie jednak z województw: białostockiego, warszawskiego i lubelskiego. Ludność przybyła z ziem wschodnich stanowiła znikomy

${ }^{23}$ W.B. ŁACH, Doświadczenia i wnioski z wojskowego wykorzystania obszaru Wielkich Jezior Mazurskich w XX wieku, [w:] Oblicza Wojny. Armia kontra natura, t. 1, red. W. JARNO, J. KITA, Łódź 2020, s. 168.

${ }^{24}$ AWO, 8 Dywizja Przełamania, sygn. 4004/10/19, Teczka dokumentacji likwidacji Sztabu 8 Dywizji Artylerii, karty bez paginy. 
procent (w 1949 r. 3,7\%). To zróżnicowanie etniczne i kulturowe nie sprzyjało stabilizacji, a wręcz przeciwnie - eskalowało konflikty ${ }^{25}$.

Tak więc w Orzyszu rozpoczęto tworzenie jednostek, których stany osobowe w 1953 r. przekroczyły liczbę mieszkańców. Z jednej strony dawało to szansę na rozwój miasta, ale z drugiej tworzyło nowe konflikty i napięcia. Nie wszyscy przecież pałali „miłością” do ludowego Wojska Polskiego.

Właściwego rozmachu organizacyjnego dywizja nabrała dopiero w miesiącu październiku 1951 r., kiedy jednostki przybyły do nowych garnizonów prosto z poligonów. Wprawdzie w Orzyszu na ich przyjazd poczynione zostały pewne przedsięwzięcia, ale pojawiły się trudności. Z powodu nieprzygotowanych mieszkań, dowództwo zmuszone było umieszczać rodziny w izbach żołnierskich. Zbliżająca się jesień, a wraz z nią chłody i deszcze dawały się we znaki jednym i drugim. Kasyna oficerskie w początkowym okresie nie były przygotowane na wyżywienie takiej ilości ludzi, tym bardziej, że odbywały się remonty bieżące. Brak było podstawowych produktów żywnościowych. Dało się odczuć niezadowolenie kadry i ich rodzin. Kadra w sposób niedwuznaczny zrozumiała, że sprawa ostatecznego przeniesienia do garnizonu zapadła bezpowrotnie.

To niezadowolenie $\mathrm{w}$ początkowym okresie służby w nowym garnizonie wpłynęło negatywnie na stosunki z miejscową władzą i ludnością. Tak duże zgromadzenie wojska musiało powodować różnego rodzaju konflikty i kwestie sporne. W dokumentach m.in. Komitetu Powiatowego Polskiej Zjednoczonej Partii Robotniczej w Piszu z maja 1954 r. podkreśla się naruszenia dyscypliny przez kadrę i żołnierzy wywoływane spożywaniem alkoholu. Szczególnym miejscem były zabawy ludowe, gdzie dochodziło do licznych bójek. Z kolei pobicie komendanta Milicji Obywatelskiej w Drygałach nie było jedynym „występkiem” wobec milicjantów. Na tę sytuację nakładał się bliżej nieznany konflikt wokół udziału oficjalnych przedstawicieli wojska w przygotowaniach, a następnie w samych obchodach, majowego święta w 1954 r. To ostatnie wydarzenie świadczyłoby o konflikcie dowództwa garnizonu Orzysz z miejscowymi strukturami partyjnymi ${ }^{26}$.

${ }^{25}$ Pisz z dziejów..., s. 191-192; Orzysz - historia...

26 W. BRENDA, „...Niezdrowa sytuacja w jednostkach wojskowych.... Dokument z 1954 r., „Debata” 2018, nr 2(125), s. 25-26. 
Asymilacji wojska ze społeczeństwem nie sprzyjały również częste przeniesienia oficerów. Nie najlepszy był również w oczach społeczeństwa obraz kadry, która okazywała wyższość wobec współobywateli. Był to efekt nie najwyższej kultury, jak i wykształcenia oficerów, których w tamtym okresie nie obowiązywał wymóg matury. Znane było hasło z pierwszej połowy lat pięćdziesiątych: „Nie matura, a chęć szczera zrobi z ciebie oficera”.

Polepszenie obopólnych relacji następuje po 1956 r. Zmiany polityczne dają nadzieję na poprawę relacji z miejscową ludnością. Nastąpiło wówczas większe otwarcie wojska na współpracę i pomoc miejscowej ludności. Mieszkańcy licznie i chętnie korzystali z zaproszeń na przeróżne organizowane w koszarach zawody. Powszechny był zwyczaj udostępniania obiektów wojskowych na imprezy sportowe. Ogromnym zainteresowaniem społeczeństwa cieszyły się również imprezy sportowo-rekreacyjne organizowane przez wojsko nad jeziorem Orzysz. Nierzadko wojsko obejmowało patronat nad przeróżnymi akcjami adresowanymi do ludności cywilnej. Niezwykle aktywna była współpraca z uczniami Szkoły Podstawowej nr 1, jak i Klubem Sportowym „Śniardwy”. W 1959 r. otwarto Klub Garnizonowy, który na długie lata stał się miejscem działalności kulturalno-oświatowej mieszkańców Orzysza i żołnierzy garnizonu. Również władze miejskie Orzysza zaczęły doceniać stacjonowanie wojska, dlatego z niepokojem obserwowano likwidację poszczególnych brygad artylerii pod koniec lat pięćdziesiątych.

\section{Rakietowy okres funkcjonowania garnizonu}

$\mathrm{Na}$ początku lat sześćdziesiątych zaplanowano wprowadzenie do wojsk nowych, decydujących o skuteczności działania na współczesnym polu walki rodzajów broni. W tym kierunku zmierzał znowelizowany „Plan zamierzeń organizacyjnych Wojska Polskiego na lata 1959-1965”. Myślą przewodnią dokumentu było lepsze przystosowanie sił zbrojnych do działań bojowych prowadzonych w warunkach powszechnego użycia broni masowego rażenia. Jednym z ważniejszych zamierzeń było wprowadzenie do wojsk związków taktycznych i oddziałów rakiet o zasięgu taktycznym (do $100 \mathrm{~km}$ ) i operacyjno-taktycznym $(50-450 \mathrm{~km})^{27}$.

27 M. TRUBAS, op. cit., s. 127-128. 
Zgodnie z planem zamierzeń na rok 1962, wyznaczono bazę formowania pierwszych jednostek rakietowych. Przyjęto propozycję sztabu artylerii WP, by stał się nią garnizon Orzysz. Za takim rozwiązaniem przemawiało szereg argumentów. W Orzyszu znajdowała się duża grupa kadry artyleryjskiej z rozformowywanych jednostek 8. Dywizji Artylerii Przełamania. Garnizon dysponował dobrą bazą koszarową oraz zapleczem przystosowanym do obsługi sprzętu technicznego. Ważnym atutem była bliskość dużego, praktycznie bezpośrednio przylegającego do koszar poligonu. Dostateczna była też komunikacja kolejowa i drogowa, a jednocześnie położenie miasta ułatwiało maskowanie i ochronę kontrwywiadowczą głęboko utajnionych wojsk ${ }^{28}$.

Jak stwierdza w swoich wspomnieniach Marian Laszczyk:

Procedury ochrony obiektu były ściśle przestrzegane i nadzorowane przez specjalnie utworzoną w Orzyszu Delegaturę Wojskowej Służby Wewnętrznej i służby kontrwywiadowczej. Główna ulica Orzysza, nosząca nazwę Wojska Polskiego, oznakowana była znakami zakazującymi zatrzymywania pojazdów przejeżdżających przez miejscowość. Życie pod specjalnym nadzorem nie było łatwe dla nas i naszych rodzin ${ }^{29}$.

Brygada, nosząca oficjalne miano 32. Łużycka Brygada Artylerii (w rzeczywistości Brygada Rakiet Operacyjno-Taktycznych, JW 2225), utworzona została w oparciu o kadrę 68. Łużyckiego Pułku Artylerii Haubic, pozostałego po 8. Dywizji Artylerii Przełamania. Zasadniczymi oddziałami brygady były dwa dywizjony rakiet operacyjno-taktycznych. Elementami zabezpieczającymi działania bojowe były: bateria dowodzenia brygady i baterie dowodzenia dywizjonów oraz kompania maszyn inżynieryjnych. Zgodnie z etatem, brygada w okresie pokoju miała liczyć 151 oficerów, 148 podoficerów zawodowych, 76 podoficerów zasadniczej służby wojskowej i 759 kanonierów i bombardierów zasadniczej służby wojskowej. W założeniu brygada miała być gotowa do wykonania zadań bojowych bezpośrednio ze stałej gotowości bojowej. Szkolenie 32. Brygady Artylerii rozpoczęło się już w grudniu 1961 r. $^{30}$

${ }^{28}$ W. BRENDA, „Transporty przychodzace do Bemowa - Piskiego byty zakryte...”. O poczatkach wojsk rakietowych w Orzyszu i Bemowie, „Debata” 2018, nr 5(128), s. 25-26; M. TRUBAS, op. cit., s. 130.

${ }^{29}$ M. LASZCZYK, op. cit., s. 183.

${ }^{30}$ Ibidem, s. 131. 
Jak stwierdza wspomniany Marian Laszczyk, wiele emocji budził przyjazd sprzętu rakietowego: „Na przełomie października i listopada na stację kolejową Biała Piska przybywały nocą transporty kolejowe ze sprzętem specjalnym w dokładnej obudowie maskowniczej. Podczas rozładowywania sprzętu i przejazdu kolumn do koszar w całym powiecie piskim wyłączono światło, a drogi przejazdu były dokładnie zabezpieczone przez patrole Wojskowej Służby Wewnętrznej i milicję" 31 .

Przygotowanie i przeprowadzenie startów rakiet wymagało doskonałego przygotowania indywidualnego wszystkich uczestniczących w nim żołnierzy oraz pełnego zgrania obsług. W tym obszarze nieocenioną rolę odegrała druga orzyska jednostka wojsk rakietowych - Ośrodek Szkolenia Artylerii (JW 1036). Został on powołany jednocześnie z 32. BA, w tym samym praktycznie kompleksie koszar. Bazą dla tworzenia jego podstawowych struktur był sztab 8. Dywizji oraz 24. Brygady Moździerzy Ciężkich. Zadaniem ośrodka było przygotowanie kadr dla mających powstać kolejnych brygad rakiet operacyjno-taktycznych. Struktura organizacyjna jednostki dostosowana była do zadań, jakie na nią nałożono ${ }^{32}$.

Po zakończeniu okresu organizacyjnego w lipcu 1964 r., 32. brygada przeszła w podporządkowanie dowódcy Warszawskiego Okręgu Wojskowego i wykonywała zadania właściwe dla armijnej brygady rakiet operacyjno-taktycznych. Główną treścią jej działalności służbowej było utrzymanie ciągłej najwyższej gotowości bojowej i nieprzerwanej zdolności do natychmiastowego podjęcia działań związanych z przygotowaniem i przeprowadzeniem startów rakiet. Brygada przygotowywała się do osłony mobilizacyjnego i operacyjnego rozwinięcia wojsk okręgu oraz udziału w pierwszym zmasowanym uderzeniu jądrowym frontu i w miarę możliwości, wsparcia uderzeniami działań wojsk na kierunkach operacyjnych: mazursko-pomorskim, północno-nadmorskim i jutlandzkim. Operacyjne zadania brygady nie zmieniały się zasadniczo w całym okresie jej istnienia. Modyfikowano głównie ich treść, zgodnie ze zmieniającymi się warunkami. Niezmiennie wymagały one jednak utrzymania wysokiej gotowości i zdolności bojowej ${ }^{33}$.

\footnotetext{
31 M. LASZCZYK, op. cit., s. 182.

32 M. TRubas, op. cit., s. 134.

33 M. TRUBAS, op. cit., s. 139-140.
} 
Jednak „sława” Orzysza, co prawda w późniejszym okresie, związana była $\mathrm{z}$ istnieniem na terenie tutejszego garnizonu tzw. kompanii karnej, budzącej respekt w całym Wojsku Polskim. 7. Oddział Dyscyplinarny (JW 1370) utworzony został w kwietniu 1971 r., a zlikwidowany w 1991 r. Osławiona kompania karna miała „przykryć” funkcjonowanie jednej z najbardziej tajnych jednostek, jaką była brygada rakietowa ${ }^{34}$.

Ostatecznie w wyniku zamierzeń restrukturyzacyjnych, zarządzeniem Szefa Sztabu Generalnego WP nr 023/org. z 28 lutego 1989 r. w sprawie rozformowania Wojsk Rakietowych i Artylerii, z dniem 31 października 1989 r. przestała istnieć 32. Brygada Rakiet Operacyjno-Taktycznych. Na bazie brygady utworzono 32. Ośrodek Szkolenia Specjalistów Wojsk Rakietowych i Artylerii ${ }^{35}$.

Orzysz na przełomie lat pięćdziesiątych i sześćdziesiątych nie był atrakcyjnym garnizonem. Słaby rozwój gospodarczy i kulturalny potęgowały poczucie tymczasowości i niepewności. Sformowanie 32. Brygady Artylerii diametralnie zmieniło sytuację, pojawiła się bowiem wielka i nowoczesna jednostka, obsadzona dużą ilością kadry o wysokich kwalifikacjach ogólnych i fachowych. W odczuciu społeczeństwa pojawienie się nowej jednostki oznaczało przede wszystkim, że miasto nie jest skazane na zapomnienie.

Brygada oddziaływała na otoczenie nie tylko biernie, poprzez samą swoją obecność. Wpływała na nie przede wszystkim poprzez włączenie się w miejscowe społeczeństwo. Uznawano też, że żołnierzy brygady cechuje na ogół wysoka kultura osobista. Podkreślali to pełniący służbę w brygadzie żołnierze zasadniczej służby wojskowej, a przede wszystkim - powoływani na ćwiczenia żołnierze rezerwy. Procesowi temu sprzyjał młody wiek żołnierzy zawodowych. Znaczna ich część, przede wszystkim podoficerów, związała się poprzez małżeństwa z miejscową ludnością. Zjawisko to, choć w mniejszym stopniu, dotyczyło także oficerów.

34 W. BRENDA, Militarne dzieje..., s. 163.

35 Archiwum Wojskowe w Nowym Dworze Mazowieckim, sygn. 1272/96.271, SG WP, Zarząd I, Teczka nr 64/III, zarządzenie Szefa Sztabu Generalnego WP nr. 023/org. z 28 II 1989 r. w sprawie rozformowania Wojsk Rakietowych i Artylerii; W.B. ŁACH, Wptyw transformacji ustrojowej na zmiany w systemie obrony na obszarze pótnocnej Polski, [w:] Misja wojskowa. Strategia i bezpieczeństwa państwa. Szkic o sitach zbrojnych, red. T. PANECKI, J. SMOLIŃsKI, Warszawa 2019, s. 405-406; W.B. ŁACH, Doświadczenia i wnioski..., s. 169. 
Surowy reżim tajemnicy wojskowej nie zezwalał na demonstrowanie sprzętu brygady, jej szkolenia lub pracy bojowej. Przeciwnie, czyniono wszystko, by (z niewielkim zresztą skutkiem) ukryć charakter jednostki. Lecz to nie rodzaj jednostki, choć budził on zainteresowanie, był ważny dla otoczenia. Najważniejsze było pojawienie się na ulicach wielu młodych wojskowych, którzy zachowaniem wyraźnie odbiegali od poprzedników. Zauważono też i szeroko komentowano obecność żołnierzy podczas licznych prac społecznych w mieście. Dużo wolnego czasu żołnierze poświęcili na przygotowania do oddania w 1966 r. nowej szkoły tysiąclecia (Szkoła Podstawowa nr 2) i Liceum Ogólnokształcącego. Potrzeba otwarcia nowych szkół wynikała m.in. ze wzrostu ilości dzieci, na których liczbę miała wpływ kadra, która służyła w garnizonie. Szczególnie chodzi o młodszą kadrę, która zakładała rodziny i mieszkała w Orzyszu. Był to widoczny wzrost rangi miasta, jak i też liczby mieszkańców. W 1969 r. Orzysz liczył 5200 mieszkańców ${ }^{36}$.

Bez utraty charakteru miasta silnie związanego z wojskiem - przy akceptacji władz miejskich - rozbudowywana była infrastruktura wojskowa. W $1968 \mathrm{r}$. oddano do użytku nowy Hotel Garnizonowy oraz rozpoczęto budowę mieszkań dla kadry. Powstały dwa osiedla budynków wielorodzinnych wraz z infrastrukturą, rozwiązując tzw. problemy mieszkaniowe kadry ${ }^{37}$.

W latach siedemdziesiątych coraz częściej brygada gościła przedstawicieli społeczeństwa na odbywających się w koszarach uroczystościach. Największą jednak popularnością cieszyły się uroczystości z udziałem wojska odbywane w mieście. W stanie wojennym żołnierze brygady wykonywali zadania wyłącznie w garnizonie. Sprowadzały się one do funkcji ochronnych. Rozsądna działalność brygady w tym okresie dobrze zapisała się w pamięci mieszkańców Orzysza. Nie mogło być zresztą inaczej, gdyż zbyt silne i wielopłaszczyznowe były powiązania brygady z miastem.

Nie wszystkie aspekty działalności żołnierzy brygady były równie pozytywnie odbierane przez współobywateli. Zdarzało się, że wzajemne kontakty przybierały formy patologiczne. W kilku przypadkach praca żołnierzy na rzecz społeczeństwa stawała się okazją do popełnienia nadużyć. Częste były też zadrażnienia z młodzieżą cywilną. W skrajnych przypadkach dowódca garnizonu

\footnotetext{
36 Orzysz-historia...; Piszz zdziejów..., s. 270.

37 Orzysz- historia...
} 
stosował nawet nadzwyczajne środki zapobiegawcze. Zdarzały się też ekscesy wywołane przez żołnierzy pod wpływem alkoholu, lecz nie przypominały one wydarzeń z lat pięćdziesiątych.

W okresie istnienia brygady zapewne nikt do końca nie zdawał sobie sprawy z jej miastotwórczej roli. Z obecnej perspektywy jest to już widoczne, zwłaszcza gdy spojrzymy na podobne miejscowości, gdzie funkcjonowanie garnizonu stanowi niemalże o istnieniu miasta (Węgorzewo, Bartoszyce czy Morąg).

$$
* * *
$$

Jak wynika z zaprezentowanych dziejów Orzysza, począwszy od XVIII w., podstawowym warunkiem stymulującym funkcjonowanie i rozwój miasta było i jest nadal istnienie garnizonu wojskowego. W tym krótkim artykule przedstawiono, jak ogromny był wpływ wojska na to miasto. Niestety, nachalna ideologizacja, jakiemu poddane zostało wojsko w okresie ludowego Wojska Polskiego, sprawia, że musimy podchodzić krytycznie do jego wykorzystania, zwłaszcza do realizacji celów politycznych.

Wyraźny podział funkcjonowania garnizonu na okres artyleryjski i rakietowy wynika z wielu czynników. Należy do nich zaliczyć m.in. sytuację społeczno-polityczną, stosunek społeczeństwa do zastanej rzeczywistości, poziom intelektualny kadry czy kondycję gospodarczo-ekonomiczną Orzysza. Pierwszy okres cechuje tymczasowość, widać wyraźną nieufność, a nawet wrogość w kontaktach między mieszkańcami a kadrą, która przybyła do garnizonu nie z własnej woli i chce się jak najszybciej przenieść. Jednocześnie okres stalinizmu każe wszędzie widzieć wrogów, więc kontakty są ograniczane. Oczywiście wojsko pomaga społeczeństwu, prowadzi wiele akcji, które wspierają mieszkańców (rozminowanie, odgruzowanie czy pomoc w rolnictwie), ale są one realizowane na rozkaz i nie przyczyniają się do powstania trwałych więzi ani stałej współpracy.

Sytuacja zmienia się po 1956 r., kiedy następuje większa integracja i pojawia się chęć współpracy. Mieszkańcy zauważają, że tak liczna obecność jednostek wojskowych daje zatrudnienie i stabilizację. Niepewność jutra wkrada się, gdy przychodzą rozkazy o rozwiązywaniu poszczególnych jednostek 8. Dywizji Przełamania. Na szczęście dla miasta, zlokalizowano w nim jedną z najnowocześniejszych jednostek, jaką była 32. Brygada Artylerii. Nie sposób ocenić, jaki 
wpływ mieli rakietowcy na kulturalny i społeczno-ekonomiczny rozwój miasta, jednak można przyjąć, że usytuowanie w Orzyszu centrum przygotowania specjalistów najnowocześniejszego w owym czasie rodzaju wojsk było czynnikiem miastotwórczym.

W momencie zmian systemowych, po 1990 r. i likwidacji utajnionych jednostek, które z obowiązku były objęte ochroną kontrwywiadowczą, wydawać by się mogło, że sytuacja i kondycja miasta się zmieni, skoro - zdaniem wielu mieszkańców czy publicystów - ubył główny czynnik blokujący rozwój miasta. Weźmy pod uwagę liczbę mieszkańców: w 1969 r. Orzysz liczył 5200 mieszkańców, a obecnie 5615. Lata dziewięćdziesiąte nie wygenerowały żadnego pomysłu na nowy kierunek rozwoju miasta, a zmiany polityczno-militarne spowodowały, że garnizon wojskowy, a zwłaszcza jego poligon, jest potrzebny i stymuluje rozwój miasta. Najlepszym przykładem akceptacji takiej sytuacji jest stworzenie przez władze miasta Muzeum Wojska, Wojskowości i Ziemi Orzyskiej, które promuje dzieje miasta u boku wielkiego poligonu.

\section{BIBLIOGRAFIA}

\section{Źródła archiwalne}

Archiwum Wojskowe w Nowym Dworze Mazowieckim

Sztab Generalny Wojska Polskiego, Zarząd I, sygn. 1272/96.271.

Archiwum Wojskowe w Oleśnicy

8 Dywizja Przełamania, sygn. 4004/10/8; 4004/10/19.

Centralne Archiwum Wojskowe - Wojskowe Biuro Historyczne

Sztab Generalny WP, sygn. IV.501.1/A.164.

\section{Opracowania}

15 Giżcka Brygada Zmechanizowana im. Zawiszy Czarnego 1994-2016, red. R. Kempa, A. Prokopczuk, Giżycko 2016. 
Brenda W., Militarne dzieje Ziemi Piskiej wXXw., [w:] Dzieje Militarne Krainy Wielkich Jezior Mazurskich, red. W.B. Łach, D. Radziwiłłowicz, S. Janowicz, Wilkasy 2013, s. 133-169.

Brenda W., „...Niezdrowa sytuacja w jednostkach wojskowych...”. Dokument z 1954 r., „Debata” 2018, nr 2(125), s. 25-26.

Brenda W., „Transporty przychodzace do Bemowa - Piskiego byty zakryte...”. O poczatkach wojsk rakietowych w Orzyszu i Bemowie, „Debata” 2018, nr 5(128), s. 25-26.

Bujas P., Blokhauzy wieżowe wezta oporu Ruciane-Guzianka, „Forteca” 1997, nr 1, s. 24-30.

Garnizony artyleryjskie na Warmii i Mazurach, cz. 1: Artyleryjskie rzemiosto. Wspomnienia żotnierzy 1 Berlińskiego Putku Artylerii w Bartoszycach, red. E. Pawlica, Węgorzewo 2014.

Garnizony artyleryjskie na Warmii i Mazurach, cz. 2: Artyleria Polska wXX wieku. W 70 rocznice powstania 1 Warszawskiej Brygady Artylerii Armat im. gen. J. Bema $w$ Wegorzewie, red. W.B. Łach, Węgorzewo 2014.

Kołodziej W., Ostróda miasto garnizonowe, Ostróda 2011.

Kowalski L., Proces przejmowania bytych ziem Prus Wschodnich w granice państwa polskiego. Aspekty polityczno-gospodarczo-militarne, [w:] Dziatania militarne w Prusach Wschodnich, red. W. Wróblewski, Warszawa 1998, s. 343-414.

Laszczyk M., Zapisane w pamięci, Warszawa 2004.

Łach W.B., Doświadczenia i wnioski z wojskowego wykorzystania obszaru Wielkich Jezior Mazurskich w XX wieku, [w:] Oblicza Wojny. Armia kontra natura, t. 1, red. W. Jarno, J. Kita, Łódź 2020, s. 155-171.

Łach W.B., Warmia i Mazury w systemie obronnym Polski po II wojnie światowej - jednostki liniowe Wojska Polskiego w wybranych garnizonach, [w:] Wojsko Polskie w nowej rzeczywistości spoteczno-politycznej po II wojnie światowej, t. 2, red. H. Łach, Olsztyn 2016. s. 169-190.

Łach W.B., Wptyw transformacji ustrojowej na zmiany $w$ systemie obrony na obszarze pótnocnej Polski, [w:] Misja wojskowa. Strategia i bezpieczeństwa państwa. Szkic o sitach zbrojnych, red. T. Panecki, J. Smoliński, Warszawa 2019, s. 398-409.

Piszzdziejów miasta i powiatu, red. W. Korycka, Olsztyn 1970.

Rużewicz W, Fortyfikacje nowożytne Prus Wschodnich, Przewodnik, Łódź 2006.

Trubas M., Kolebka polskich wojsk rakietowych, [w:] Z dziejów Wojska Polskiego na Warmii i Mazurach po drugiej wojnie światowej, red. W.B. Łach, Węgorzewo 2004, s. 123-148.

Warszawski Okrę Wojskowy. Historia i wspótczesność, red. W. Rozbicki, Warszawa 1997.

Ziemia Orzyska. Arys... Pamiętam takie miasto. I remember such city, Orzysz 2019.

Ziniewicz M, Wojskowa infrastruktura techniczna z czasów I wojny światowej obecnie wykorzystywana przez resort obrony narodowej, [w:] Wielka wojna na Mazurach 1914-1915. Studia z dziejów frontu wschodniego I wojny światowej, red. R. Kempa, Węgorzewo 2014, s. 419-431. 


\title{
Netografia
}

Orzysz - historia, www.orzysz.pl (dostęp: 2 I 2020).

http://ospwlorzysz.wp.mil.pl/ (dostęp: 8 I 2021).

\section{Wiesław Bolesław Łach \\ UNITS OF ROCKET AND ARTILLERY TROOPS IN THE ORZYSZ GARRISON AFTER 1945 - INFLUENCE ON THE DEVELOPMENT AND FUNCTIONING OF THE CITY}

\begin{abstract}
Summary. The paper presents the development and functioning of the Orzysz as a town inextricably linked with the army from the mid- $18^{\text {th }}$ century. The Second World War, and especially the arrangements of the Allies in Tehran and Yalta, changed the face of the city. Orzysz found itself within the Polish borders to a great extent depopulated and destroyed. However, the former German military infrastructure remained intact in it, which became, from 1948, a place of dislocation of artillery units and, in the 1960s, rocket units of the Polish Army.

The role of the military was important after the war from a demographic point of view. It became a guarantor of security and lost lands in the East for the people coming from central Poland to Masuria. The economic development of the Orzysz that took place at that time was conditioned by the needs of serving soldiers and professional staff. The members of the city's civil life were also the families of the military staff living there. Military counterintelligence protection was also carried out in the garrison. It had a negative impact on the development of some economic branches of the city, especially tourism and culture. Over the years, this situation has reduced the city to a service role, to a greater extent in relation to the needs of the army and the environment associated with it.
\end{abstract}

Keywords: Polish Army, Orzysz, garrison, inhabitants, rocket and artillery troops 